EDUKACJA MIĘDZYKULTUROWA

\title{
European clubs or euroclubs as forms of introducing intercultural education and innovative technologies
}

Streszczenie: Rozważania podjęte w artykule dotyczą związków akademickich oraz Szkolnych Klubów Europejskich (Euroklubów) jako ośrodków kształtowania tożsamości międzykulturowej oraz wprowadzania innowacyjnych technologii w warunkach pracy państwowych instytucji szkolnictwa średniego. Artykuł ukazuje, że Szkolne Kluby Europejskie oddziałują na formowanie osobistego nastawienia uczniów szkoły średniej do współczesnego życia i społeczeństwa, ich postawy życiowej i obywatelskiej. Eurokluby pomagają również uczniom stwarzać warunki do odkrywania swoich możliwości samoedukacyjnych, samooceny i samorealizacji oraz zapewniają tworzenie świadomości europejskiej i harmonijnie rozwijanej osobowości, w kontekście europejskiego wymiaru edukacji.

Słowa kluczowe: Euroklub, świadomość europejska, edukacja międzykulturowa, technologie innowacyjne, samowiedza, samoocena i samorealizacja, europejski wymiar edukacji

The main task of any educational system consists in the perpetuation of national culture and national consciousness as well as in opportune change aimed at a person's balanced development.

Due to the developing relationships between the European Union and Ukraine, a problem appears associated with arranging some organizations which could unite and give guidance to the youth in the issues of European integration policy of Ukraine.

The European choice of Ukraine is stipulated by its geographical and political situation, combining the history of forming and developing of European culture. The foundation of the Ukrainian national policy on a way to the European Union and of the forming of new politics of the European Union to Ukraine is informing the population about the history of the European Union, economic collaboration with the member states, the standards of life 
in European countries, legal and social defense of citizens. Some important issues of the democratic society are: civil culture, competence, respect to the human rights, tolerance, ability to compromise, European values. It is necessary that citizens know the rights and duties resulting from the law and can think critically and independently.

In the conditions of modern life, the national strategy for the development of education in Ukraine for 2012-2021 determines the integration to the European and world educational space that will provide advancement of education and will enable a substantial increase in the intellectual, cultural, spiritual, moral potential of the society and the individual ${ }^{1}$.

In this context, special attention is paid to the organization of students' after school activities - to the creation and functioning of public associations for children, Euroclubs, and to the conditions of work in state secondary educational establishments.

It should be mentioned that teenagers try to expand their contacts and their social relations using online means, communicating in social networks like Facebook or Twitter. These virtual groups are based on common interests. Euroclubs are children's associations that expand the number of methods working with secondary school students and can be an alternative to online groups, providing opportunities for teachers-coordinators (through targeted measures) to influence the process of educating secondary school students in extracurricular activities.

In the context of the activities of Euroclubs as centers of multicultural education, the personality that is aware of the necessity of establishing common European values has the ability to think critically and to solve problems creatively. Secondary school students, with their conscious perception and understanding of the world and of the processes taking place in it, form their own system of views on the issues of both European and national identity, proclaimed by the Council of Europe's list of competences.

School European Club or Euroclub is one of the most effective forms of extracurricular work which assists students' mastering of the European issues as a new dimension. It is also a collective students' and teachers' work that deepens the knowledge of Europe and European integration, distributes information on this theme at schools and in local associations. The first Eu-

1 Nacionalna strategiya rozvitku osviti v Ukraini na 2012-20121 roky // Materialy III Vseukrains'kogo z’izdu pracivnikiv osviti / Kyiv, Chernivci: Bukrek, 2011. - 400 s.: il. - s. 317-374. 
ropean clubs were founded in Portuguese schools and later spread all over Europe ${ }^{2}$.

The activity of Euroclub is aimed at students of the $1-11^{\text {th }}$ grade who show personal interest in the study of the English language, history, geography, and the structure of the European society. The work of Euroclub is based on the principles of voluntariness, activity and personal interest of students.

It is necessary to notice the importance of combining both the classes and extracurricular activities for Euroclub processes. Extracurricular work allows to extend the active vocabulary of students, to perfect oral and writing skills, to enhance interest in the study of objects, in particular foreign languages, to bring up tolerance, patriotism and multiculturalism. It is necessary to notice that exactly these components of education are a priority in compliance with the Ukrainian act «On education $»^{3}$, the national doctrine of the development of education ${ }^{4}$ and the national strategy for the development of education in Ukraine for 2012-2021 .

The main tasks of Euroclub activity are the following

- learning of European history, culture, traditions, and customs;

- spreading information about the prospects of integration processes in Europe;

- establishing contacts with the youth of European countries through exchange programmes, writing letters or e-mails, realizing different projects; on-line communication;

- holding events to inform the society about the European Union, European organizations, the European community in general;

- forming communicative and analyzing skills and critical thinking;

2 L. Parashchenko: Yak organizuvati shkil’niy evroklub: Metodychni rekomendacii z organizacii pozaklasnoi roboty. - K.: Mizhnarodniy fond „Vidrodzhennya”, 2004. s. 24 .

3 Zakon Ukrainy «Pro osvitu». [Elektronnyy resurs]: Zakonodavchi akty Ukrainy z pytan' osvity. Za stanom na 1 kvitnya 2004 r. - Rezhim dostupa: http://zakon2.rada. gov.ua/laws/show/1060-12.

4 Ukaz Prezidenta Ukrainy «Pro Nacional'nu doktrinu rozvitku osvity». [Elektronnyy resurs]: Ukaz Prezidenta Ukrainy vid 17 kvitnya 2002 roku N347/2002. - Rezhim dostupa: http://www.president.gov.ua/documents/151.html.

5 Nacionalna strategiya rozvitku osviti v Ukraini na 2012-20121 roky // Materialy III Vseukrains'kogo z’izdu pracivnikiv osviti / Kyiv, Chernivci: Bukrek, 2011. - 400 s.: il. - s. 317-374. 
- improving skills of informational technologies;

- motivating to learning of foreign languages.

The effective functioning of the European club as a centre of multicultural education for secondary school students is based on the following major principles: 1) the principle of universal equality; 2) the principle of mutual aid; 3) the principle of cognitive activity and creativity; 4) the principle of the pyramid; 5) the principle of personal orientation; 6) the principle of cultural appropriateness.

All these principles are analysed below:

1. The principle of universal equality. Activity in the Euroclub is conducted on a voluntary basis. According to a person-oriented approach, each member chooses his/her pace of moving towards the goal, of fulfilling the mission in terms of the activities of the European club as a whole.

2. The principle of mutual aid. The organizational structure of the European club activities is built in such a way that it is strategically necessary to master the knowledge and skills by all members of the club as fast as possible. That is why the principle of reciprocity becomes important: by helping others, a member of the club him/herself acquires invaluable experience.

3. The principle of cognitive activity and creativity. The students-leaders of the European club are given the opportunity to express themselves creatively in a relaxed and comfortable environment that promotes their further development as individuals.

4. The principle of the pyramid. The organizational structure of the European club has a vertical hierarchy, that is, at the head of the children's public association there is a leader who directs the activities of all members. This structure allows a large number of students to take part in the process of the European club activity, giving them the opportunity to explore issues in which they have a direct interest and work together to reach a goal.

5. The principle of personal orientation. The content of the programmes and activities of the European club generally takes into account the individual characteristics of each student, it creates "a situation of success" and a comfortable atmosphere for cognitive activity.

6. The principle of cultural appropriateness. The activities of the European club involve the assimilation by students-leaders of cultural values, the formation of the individual's needs concerning self-development, the 
awareness of national identity, the culture, lifestyle, traditions of other countries.

For the expansion of students' world view and their erudition, there is some possibility to activate the intellect by participating in various competitions, quizzes, projects, on-line contests in the programme of Euroclub activity.

Thus, there is the forming of skills of participating in different events and activities as well as the skills of understanding the national and cultural features of people, respecting their traditions, language, lifestyle, the forming of skills concerning collective work, critical thinking, ability of brief and well-argumented proving of the standpoint This ensures the forming of European consciousness and the harmonious development of personality in the context of European dimension in education. Therefore, the primary purpose of Euroclub activity is forming the social, political and public position of students' personality.

Considering the extraordinary popularity and interest of students in the use of the Internet and information and communication technologies, it seems to be a logical application of their capabilities in the educational process.

One of the most effective methods of the use of the Internet in the educational process in the conditions of activity of the European club within general educational institutions is a web-quest. Web-quest in pedagogy aims to address issues through the use of Internet resources ${ }^{6}$.

The main feature of using web quests is that the information presented on the website for independent or group work of students is important for them - they use it for the collection and compilation, as well as communication, exchange of information, further analysis, forming conclusions concerning the conducted work.

The following stages in the use of the web quest are distinguished:

- introduction (a brief description of the topic of the web quest and the timing of the assignment);

- formation of a task (the wording of the issue and the characteristics of the final presentation of results, motivation of students);

6 O. N. Bobrovskikh: Ispol'zovanie veb-kvestov v obuchenii (na primere angliyskogo yazyka). // Internet-zhurnal Centra distancionnogo obrazovaniya «Eydos». - 2008. - 16 dekabrya. http://www.lengto.ru/publ/metody_obuchenija/ispolzovanie_veb_ kvestov_v_obuchenii_na_primere_anglijskogo_jazyka/5-1-0-68. 
- setting of the algorithm to perform the work and list of Internet links that are required to perform tasks (instruction on the stages of the work, the provision of a list of key words or questions to seek information, views, useful links on the Internet that will help to solve the task and the criteria by which the evaluation will be conducted of the final product activity);

- discussion and evaluation (updating a supplementary knowledge, the presentation of the main characteristics, the design of generalized information, answers to problem questions in the form of abstracts, presentations, conferences, blogs, roundtables, etc.);

- conclusions (providing information regarding the knowledge, abilities and skills which the student cam acquire in the process);

- comments and recommendations (basic guidelines for further work, the analysis of results) ${ }^{7}$.

Thus, web-quests not only increase the interest in the subject and the general awareness, but also help to develop skills of teamwork, critical thinking, ability to classify, to analyze and lay the foundation for further research activities.

At the present moment, the approach of Euroclubs activity in state secondary educational institutions is understood as the orientation of the educational process towards the development of abilities and skills of the individual, the practical application of the acquired knowledge in different academic subjects, successful adaptation of the person in society, professional self-fulfillment, the formation of skills of collective acting and self-education.

The principle of the approach is that the student receives knowledge not in a finished form but produces it him/herself in the process of educational activities, which contributes to its cultural and activity-based abilities. The activity-based approach of Euroclubs aims to develop the skills and abili-

7 Informacionnye technologii obucheniya yazyku. [Elektronnyy resurs]. Rezhim dostupa: http://www.itlt.edu.nstu.ru/webquest.php\#lit9\#lit9; O. V. Ilchenko: Vykoristannya veb-kvestiv u navchalno-vyhovnomu procesi. [Elektronnyy resurs]. Rezhim dostupa: http://osvita.ua/school/lessons_summary/edu_technology/30113/ Використання web-квестів у навчально-виховному процесі; Selecting a WebQuest Project. [Electronic resource]. - Access mode: http://webquest.sdsu.edu/project-selection.html; The WebQuest Design Process. [Electronic resource]. - Access mode: http:// webquest.sdsu.edu/designsteps/index.html; T. A. Blokhina: Veb-kvest - kak novaya tehnologiya problemnogo obucheniya $v$ sisteme rossiyskogo obrazovaniya. [Elektronnyy resurs]. - Rezhim dostupa: http://www.t-blohina.com/news/veb-kvest-tekhnologii/. 
ties of the learner, the applications of the acquired knowledge in practical situations, and the search for ways of integration into the sociocultural and natural environment.

The Euroclub activity-based approach is seen as the process of developing joint activities with representatives of other cultures and it provides:

- the Euroclub coordinator's contribution to the development of cognitive motives of secondary school students through cooperation;

- the changing role of the learner from a passive recipient to an active information seeker, a scientist developing activity and independence in the process of mastering knowledge;

- performing certain actions, with the aim of acquiring the necessary abilities and skills, their control, and conscious practical application in solving actual problems;

- encouraging students to various activities, with a view to their preparation for independent life in the multicultural world.

The results of the leaders' activity in Euroclubs also include the establishment of intercommunication and collaboration with the Euroclubs in the region, Ukraine, international partners from European countries and CIS, as well as participating in numerous competitions, projects, and events of different prganizational levels.

Students' activity in secondary school Euroclubs results in active participation in public and cultural life, provides an increasing realization of important European issues and the assistance in getting unique educational experience for young people.

Moreover, it should be admitted that the youth's constructive and pragmatic attitude to Ukrainian integration in Europe is formed, as well as skills of collaboration and partnership are developed. What should be mentiond is an increase in students' interest in the history of the European Union, in the analysis of all advantages and disadvantages of the integration process, and also tn the realization of the Ukrainian role in the European Union and Europe in general. The co-ordinators of Euroclub really make efforts to reassure the young that this is the way to the development of democracy and civil society.

Thus, the importance needs to be stressed of stage-by-stage work for creation and organization of Euroclub activity in the conditions of the secondary educational establishment which enhances effective organization of the educational process in extracurricular time. What also seems worth mentioning 
is the gradually growing role of students-leaders who make the activity of Euroclub an autonomous constituent of educational work within secondary educational establishments.

Secondary school students who take active part in Euroclub activity show interest and flexibility in intercultural communication, the ability to take into account the peculiarities of the situation and the partners for joint activities, the ability to build a constructive relationship. To avoid creating critical situations, they are able to overcome stress and they are able to work effectively both independently and as a team with representatives of other cultures. They are capable to search, store, use, analyze and disseminate important information using modern means of interactive on-line communication.

As a result, what can be observed is the formation of multicultural education of secondary school students, of their ability to adapt and exist in a multicultural society and to interact with representatives of various countries and cultures. Students are active participants in various international programmes and projects aimed at the exchange of experience, they are motivated by self-improvement and self-realization, have the opportunity to study abroad and to cooperate with representatives of other cultures. Secondary school students who take active part in Euroclub activities differ by a stable moral value orientations and the quest for self-realization and self-improvement. They have an active and creative approach to duties, are able to produce original ideas, make decisions in unusual situations and take responsibility for themselves, think critically and analyze.

They are characterized by highly developed skills of dialogue and monologue expression, a tolerant attitude to other cultures, ability to choose optimal methods of communication, including on-line communication, with the representatives of other cultures. They are able to present themselves at the proper level, they know how to reason correctly and how b to defend their own standpoint, they are guided by the norms of ethics.

This approach enhances the further effective functioning of Euroclub as a centre of multicultural education of secondary school students. By creating terms for official communication, students begin to acquire skills necessary for life in the multicultural world, they not only undertake serious study to form and report their opinion to wider public, but also respectfully follow their judgements, realizing the importance of command labour for the achievement of the assigned tasks. 


\section{Bibliography}

Blokhina T. A.: Veb-kvest - kak novaya tehnologiya problemnogo obucheniya $v$ sisteme rossiyskogo obrazovaniya. [Elektronnyy resurs]. - Rezhim dostupa: http://www.t-blohina.com/news/veb-kvest-tekhnologii/.

Bobrovskikh O. N.: Ispol'zovanie veb-kvestov v obuchenii (na primere angliyskogo yazyka). // Internet-zhurnal Centra distancionnogo obrazovaniya „Eydos”. - 2008. - 16 dekabrya. http://www.lengto.ru/publ/metody_obuchenija/ispolzovanie_veb_kvestov_v_obuchenii_na_primere_anglijskogo_jazyka/5-1-0-68.

Ilchenko O. V.: Vykoristannya veb-kvestiv u navchalno-vyhovnomu procesi. [Elektronnyy resurs]. - Rezhim dostupa: http://osvita.ua/school/ lessons_summary/edu_technology/30113/ Використання web-квестів у навчально-виховному процесі

Informacionnye technologii obucheniya yazyku. [Elektronnyy resurs]. Rezhim dostupa: http://www.itlt.edu.nstu.ru/webquest.php\#lit9\#lit9.

Nacionalna strategiya rozvitku osviti v Ukraini na 2012-20121 roky // Materialy III Vseukrains'kogo z'izdu pracivnikiv osviti / Kyiv, Chernivci: Bukrek, 2011. - 400 s.: il.

Parashchenko L.: Yak organizuvati shkil'niy evroklub: Metodychni rekomendacii z organizacii pozaklasnoi roboty. - K.: Mizhnarodniy fond «Vidrodzhennya», 2004.

Selecting a WebQuest Project. [Electronic resource]. - Access mode: http:// webquest.sdsu.edu/project-selection.html.

The WebQuest Design Process. [Electronic resource]. - Access mode: http:// webquest.sdsu.edu/designsteps/index.html.

Ukaz Prezidenta Ukrainy „Pro Nacional'nu doktrinu rozvitku osvity”. [Elektronnyy resurs]: Ukaz Prezidenta Ukrainy vid 17 kvitnya 2002 roku N347/2002. - Rezhim dostupa: http://www.president.gov.ua/documents/151.html.

Zakon Ukrainy „Pro osvitu”. [Elektronnyy resurs]: Zakonodavchi akty Ukrainy z pytan' osvity. Za stanom na 1 kvitnya 2004 r. - Rezhim dostupa: http:// zakon2.rada.gov.ua/laws/show/1060-12. 


\section{European clubs or euroclubs as forms of introducing intercultural education and innovative technologies}

\section{Summary}

In the article, students' associations called School European Clubs (Euroclubs) were taken into consideration as the centres of forming the intercultural personality and introducing innovative technologies in the conditions of working in state secondary education establishments. The authors reveal the fact that School European Clubs or Euroclubs have influence on the formation of secondary school students' personal attitude towards modern life and society, their standpoint in life, as well as their civic attitude. They also help students to create conditions for revealing the potentialities of self-knowledge, self-assessment and self-fulfillment, they ensure the forming of European consciousness and harmoniously developed personality in the context of European dimension in education.

Key words: Euroclub, European consciousness, intercultural education, innovative technologies, self-knowledge, self-assessment and self-fulfillment, European dimension in education 